\title{
New Generation of Universities. University 4.0
}

\author{
Alla V. Lapteva and Valerii S. Efimov* \\ Siberian Federal University \\ 79 Svobodny, Krasnoyarsk, 660041, Russia
}

Received 11.06.2016, received in revised form 22.08.2016, accepted 04.09.2016

The ongoing changes in universities are considered in the logic of change of socio-economic development phases - as an aspect of the post-industrial transition. The content of the society and university development phases is comprehended through a set of categories: "the activity-orientedthe social - the anthropological". The article identifies four "generations" of universities relevant to the pre-industrial, industrial, post-industrial and cognitive phases. In order to analyze transitions from one generation to another the authors use a model "overcoming-positing-deployment" (forms of activity, institutional forms, forms of consciousness and thinking, pictures of the world). The article also discusses features of the future University - University 4.0.

Keywords: universities, post-industrial transition, phase transformations, university in society, generations of universities, University 4.0.

The study was funded by RFH and Krasnoyarsk State Agrarian University "Krasnoyarsk Regional Fund of support of scientific and technical activities" within the framework of the research project "Universities in a situation of post-industrial transition: new features and models of development" (project No.16-16-24011).

DOI: 10.17516/1997-1370-2016-9-11-2681-2696.

Research area: economics.

\section{Introduction}

The modern world is characterized by high dynamics of socio-cultural, economic, technological, demographic and other processes of a global scale. Philosophy and social sciences consider this dynamics as a "change in technological waves", "phase transition", "anthropological revolution", while emphasizing the depth, intensity, special quality of the changes that give rise to high uncertainty about the future. The changes also cover higher education; many researchers interpret them as a multifaceted crisis (Readings, 1996), the aspects of which are a gap between the labour market needs and professional education (Gimpelson et al., 2009), a decline in the prestige of the teaching labour (Liubimov, 2009), the need to change a paradigm of education (Post-industrial transition..., 2005), etc. A utmost form of the "crisis" discourse is a judgment of the "death of the university" (Barnett, 2001); it also reflects the power of challenges faced by the university, the inadequacy of efforts to respond

(C) Siberian Federal University. All rights reserved

* Corresponding author E-mail address: efimov.val@gmail.com; avlapteva@yandex.ru 
to these challenges, and, simultaneously, the chances of the total university update.

It is important to discuss the current state of universities not as a "crisis" or "death", but within the concept of "transformation" embracing these categories. Transformation is a crisis and destruction of one socio-cultural whole and, at the same time, the creation and deployment of another. We believe that the transformation of educational institutions has a generalcivilizational nature and is related to the "phase transformation" - transition from the industrial forms of the existence of society to the postindustrial ones (Bell, 1999; Inozemtsev, 1995; Pereslegin, 2007).

In contrast to local changes the transformation involves reformation of the university as a system - its mission, functions in society and, therefore, a set of implemented activities, applied technologies and organizational forms (Efimov et al., 2012a; 2012b). The university becomes different - "another entity" corresponding to the new "version of the world".

The ongoing changes in higher education in Russia are discussed in a wide range of scientific publications, but they are much less comprehended in terms of the transformation associated with the post-industrial transition. We can highlight the report of the CSR "North-West" (Post-industrial transition..., 2005), the works of V.A. Mau (2013), T.L. Kliachko and V.A. Mau (2015), M. Galushkina and V. Kniaginin (2005), N.E. Pokrovskii (2005), D.V. Didenko and Iu.V. Latov (2013), V.S. Efimov et al. (2011; 2012a; 2012b; 2014). The researchers also consider some aspects of transformation, for example, a change in public demand for higher education, a place of universities in the creative economy I.V. Abankina et al. (2012; 2013); massification effects of the higher education - Ia.I. Kuz'minov (2007); differentiation of higher education and institutional dynamics - E.A. Kniazev, N.V.
Drantusova (2012; 2013); effects of online learning - Ia.I. Kuz'minov and I.D. Frumin (2015). A broader topic of the change in "images of education" in connection with the change of eras of socio-economic and socio-cultural development was studied by A.P. Ogurtsov, V.V. Platonov (2004), V.M. Rozin (2007).

This article presents the results of the philosophical and methodological analysis of the features of the post-industrial transition using groups of categories - the activity-related, the social, the anthropological. These categories are applied to analyze transformations and identify the main characteristics of the university as a historical type or "generation" (ideal form) corresponding to different historical eras.

\section{How to conceive the university: categories and basic schemes}

The university can be conceived as a "university in general" - a typical ideal type of the cognitive institution, the image of which is followed by specific institutions of higher education. In this case, transformation means a change in the ideal image of the university (Jaspers, 2006). On the other hand, transformations can be studied empirically as changes in the parameters of individual institutions or "populations" of universities.

To conceive universities and their transformation systematically, there is a need for an ontological structure that links different aspects of reality of universities and reflects the involvement of universities in the external socio-cultural context and the internal processes occurring in the universities. We will use the philosophical categories - "the activity-related, the social and the anthropological" as such a structure defining "mental space". To conceive the university means to "place" it in a given space, to begin to consider each of the phenomena of existence and transformation of universities in 
three projections - activity-related, social and anthropological.

\subsection{The activity-related, the social} and the anthropological - key categories

A model of the philosophical and methodological analysis, the basis of which is the group of categories "the activity-related", "the social", "the anthropological", allows us to mark out and systematically identify the key features of the complex socio-cultural objects. Phases of social development, phenomena of the existence and transformation of universities considered in three projections - activityrelated, social and anthropological - can act as these objects.

In the proposed system of categories, the university as the ideal form is characterized by the following features:

- in the activity-related dimension it contributes to the reproduction of activities in society through education and training; acts as a platform to implement a number of complex activities (research, education, design, innovation, expertise and others); serves as a platform to create new activities and shift to the deployment of new practices;

- in the social dimension it is an institutional form of a number of functions of society (a "body" of society), ensures the reproduction of social norms and relations, various forms of communication and a social structure through the reproduction of elites, reproduction of intellectuals, reproduction of such activities as management, politics, entrepreneurship; through the reproduction of ideology and the world view;

- in the anthropological dimension it reproduces a human through the transfer of value systems, packages of knowledge, world view and ideology; formation of skills, socialization; it is a space of freedom, in which the new human images, new forms and structures of personal life are anticipated, built and tested in the "experimental" mode".

The real university, as opposed to its "ideal form", may not provide a complete reproduction of activities, may not be a functional "body" of society, may not participate in the processes of reproduction of human. In this case, the most important functions of the university are performed either in a highly reduced form or by other institutions and environments of society, while the university turns, for example, into a place that issues diplomas. In a situation of the university's dysfunction there is a gap between the university and society, and the university is becoming a "lost" institute (Readings, 1996, Efimov and Lapteva, 2014).

\section{Phase transformation - the post-industrial transition}

The ongoing (or necessary) transformations of the university should be studied in the context of social transformation covering all the aspects of its existence: economic, social, cultural, anthropological. In the second half of the $20^{\text {th }}$ - early $21^{\text {st }}$ centuries, a number of sociophilosophical concepts of social transformation has been developed: A. Toffler - "the third wave"; F. Fukuyama - "the end of history"; F. Machlup (1966), T. Stouner (1986) - "the information society", D. Bell (1999) - "the post-industrial society", V. Inozemtsev (1995) - "the posteconomic social formation”, M. Castells (1999; 2000) - "the network, information society"; R. Inglehart (1997) - "the society of postmaterialist values".

\subsection{Transformation of activity systems - transition from industrial systems \\ to post-industrial ones}

A basis of the post-industrial phase transition is the transformation of activity systems such as packages of prevailing technologies and social 
and organizational forms that are characteristic of the pre-industrial and industrial phases of development.

As a result of the application of scientific and technological revolution achievements - the new production processes, digitization, robotization the industry productivity increases. In highly developed countries the proportion of people employed in the industry reduces, the share of industry in total world production has a longterm trend to decline ${ }^{2}$.

At the same time there is technologization of activity in the service and intellectual spheres, including education, healthcare, management, finance, mass media, and then - researches, consulting, assessment, design. It becomes possible to spread the industrial forms of organization - "activity organized as a mashine"across these spheres as the "factories" of training, treatment, production of knowledge, solutions, etc. Paradoxically, the share of industry in the world production is reducing, but the industrial forms of activity involving technologization, standardization, massification of production expand the scope of application.

Also the share of kinds of activities involving creation of an individual, a unique product (or service), creativity and knowledge (handicrafts individual work of a master as opposed to the activity organized as a mashine) increases.

In the context of globalization of markets and production (transition to globally distributed chains of value creation) there is localization of industries as a leading technological and socioorganizational form of activity in countries and regions where costs are minimal - cheap labour, low environmental requirements.

Finally, there is actually the establishment of post-industrial socio-organizational forms of activity. These are the self-organizing production systems and production ecosystems, including actors that are different in size, subject and type of activities in a developed information (communication) environment that provides the flexibility of co-operation, the speed of creating and applying innovations ${ }^{3}$. A compulsory component of such systems would be a "collective intelligence" in various forms, and the creation and distribution of the collective intelligence technologies ${ }^{4}$ would be the most important line of technological development.

\subsection{Transformation of economy-transition} to the post-economy, the "economy of common good"

Another aspect of the post-industrial transition is the transformation of economy as a set of different activities that gives the production of "values" or "welfare" a form of production of commodities having a cost and intended for sale.

On the one hand, the scope of commodification expands, more and more phenomena of the human world become products - knowledge, events, experiences, relationships, reputations and so on. On the other hand, the scope of production of public welfare expands, and the proportion of time that people devote to a voluntary activity for the shared benefit increases - people share knowledge and experience in social networks; present products they made for the public use; participate in voluntary activities; act as initiators of public events; publicly express their opinions and participate in the evaluation, examination of the political, economic, social, cultural and other situations.

Intellectual creation products are getting more available for the free use, including the hightech sphere requiring large expenditures, such as software with open code, databases, channels of communications, technological solutions and others.

\subsection{Communications transformation- to "universal commutability"}

The most important component of the post-industrial transition is the transformation 
of communications as a key condition for the production of new meanings, ideas and projects.

Communications transformation has: 1) a technological aspect - digital-communicative revolution, deployment of the global system of telecommunications; 2) a socio-cultural aspect - unification of languages, cultural codes, development of a reflection allowing individuals and groups, carriers of different values, cultural codes to engage in communication; 3) an anthropological aspect - significantly increased possibilities of a person to engage in relevant communications will increase the "communication power" that is important for human activity, including sense-creating, contemplating, proception, projection and design, implementation of plans and projects.

\subsection{Transformation of culture \\ and human's attitude to culture}

In a situation of the post-industrial transition, the multidirectional cultural changes will occur. We can talk about the formation of a "global culture" as a cultural community of people whose activities are not confined within the borders of certain countries or cultural and linguistic areas, but create and maintain the cross-border flows of goods, information, events, etc. On the other hand, there is an increased activity of national, religious, ethnic, professional communities, which is aimed at maintaining the processes of transmission of identity, certain institutions, types of activities, etc.

The expansion of intercultural contacts, the development of reflection in relation to the values and cultural norms leads to the transformation of culture and human's attitude to culture. It is expressed in the transformation of symbols, images, values and norms basic for different cultures into "just artefacts" that are temporary, relative and may be different. The consequence of these changes will be, on the one hand, the developed reflection, irony, playful attitude to culture, values and norms, setting for the cultural construction. For a part of the society the result will be negative: loss of cultural supports and value orientations; distancing from the complex forms of culture and "cultural orphanhood". The negative social effects also include the emergence of various kinds of simulated reality, practicables and simulacra that will deform and obsolete the existing reality.

Cultural stratification, growth of "cultural gaps" between the parts of society that were included and not included in reality of the post-industrial (cognitive) phase can become a significant trend, which will be the basis for largescale cognitive inequality, when large groups of people, nations and countries will be pushed out to the periphery of the development process. (Castells, 2000; Pereslegin 2007, Towards Knowledge Societies, 2005).

\subsection{Transformation of sociality}

(communities, relations, institutes)

Within the phase transition, society is changing as configuration of social communities, types of relations and social institutions. The industrial phase is characteristic of the fact that the social communities - a family, a work team, an ethnos, a nation - are stable (i.e., their nature does not change) within a generation, so the society is a given for an individual. The transformations of systems of activity, communications and culture lead to the fact that society becomes dynamic, especially at the level of micro-community. Thus, family becomes more variative and volatile in terms of structure and the nature of relations.

Among social relations, the regular relations forming a stable and predictable environment of human existence is less dominating. Previously, these steady relations determined human identity as a form of individual establishment in society and social structuring. In comparison with 
the industrial phase, a balance of hierarchical and horizontal relations is shifting toward the horizontal, network, environmental ones; it can be traced in relations of various types - family, corporate, political and others.

There is a new level of reflection in relation to different aspects and forms of sociality (communities, relationships, institutions, practices, traditions, patterns of behaviour, etc.). Preexisting as "natural", they begin to be considered as artificially created. It means that a person consciously accepts or does not accept the existing forms of sociality and, moreover, begins to actively participate in their development and settlement.

There is also social virtualization - it is revealed, on the one hand, through the community in the virtual reality of the Internet and, on the other hand, through virtualization of ties and relations between people and groups in the "ordinary" reality. Virtualization means the transition from connections and relations that have distinctness, predetermined meaning and structure towards redefining connections and relations the meaning and structure of which change and can be reset.

\subsection{Human transformation}

(identity, activity, consciousness)

Any basis that could be perceived as a universally human is being "melted"; there is increased mobility and conditionality of all certainties by which a person became someone and something - age, gender, professional, national.

Achievements of Genetic Engineering and Robotics in the long term will make genetic reengineering of human, cyborgization, human entry into the hybrid systems (human and artificial intelligence, etc.) possible. The increasing mobility of people (territorial, social, cultural) will make identities unstable forms of self-identity that are localized in space and time.
The human activity is shifted from the area of routine operations into the area of trial and search actions, critical and creative thinking, reconstruction of society and self-realization of an individual.

Formation of a deployed virtual (multimedia) environment will lead to multi-virtualization of a man - he will carry out trial ("game") actions at a set of virtual platforms. A personality will represent a superposition of "real" and "virtual" identities, each of which will be implemented in a variety of practices.

High diversity of cultural norms and values, dynamic society (its forms and relations) will lead to an increased uncertainty of human existence. It will be necessary to create a certain "anthropological foundation" - a culture-value platform, through which a person can remain himself without getting distracted on many temporary, conditional identities. The basis for such a platform can be a "value self-image" of a person (O.I. Genisaretskii, 1995) as a form of a set of life-creating meanings that is fixed at the individual level.

Considering the situation of the postindustrial transition, we need to define the contours of a "destination point" of the ongoing transformations. We believe that transition into a phase of the "cognitive society" will be fundamentally new for the humanity (S.B. Pereslegin, 2007), where the key factors of social production will be a collective human intelligence. Formation of the "cognitive society" will occur on the basis of the following changes:

- expansion of activity sectors related to the production of knowledge, technologies and innovations, new meanings, images and lifestyles;

- expansion of access to knowledge and the opportunity to be included in the production of knowledge and innovations of an unprecedented wide range of people; thus there is massification of higher education and enhancement of the value of an intellectual component within the production processes; 
- "cognitivization" of economy and society - enrichment of activity and leisure with knowledge; the division between those who produce knowledge and those who only uses knowledge, which is typical of the industrial world, is eliminated;

- transformation of collective intelligence into a key productive force of society; "collective intelligence of society" is formed;

- formation of a technological base for the "cognitive world", which is the achievements of the digital revolution that make it possible to translate information into a digital signal and transfer it to the networks of telecommunications "without limits", to distribute it at all scales;

- expansion of the range of cognitive technologies. If earlier it was the technologies related to the processing and transfer of data, computer memory, artificial intelligence, computer-brain interfaces, in future these technology packages will be expanded at the expense of cognitive-humanities technologies (CHT). These technologies will be linked to the exteriorization of human intellectual functions. CHT will provide the assembly and functioning of the collectively distributed intelligence, including configuration of knowledge (thinking), communications and activities.

Since the mentioned transformations occur, the university cannot remain the same. It cannot rely on the reproduction of the industrial systems of activity (corresponding professions), on economic relations, reproduction of culture, society and human with their previous (specific to the industrial phase) content and forms.

\section{Transformation of the university - logic of changes; features of the new generation of universities}

The expected transformation of universities is not the first in history of their existence. In this section, we use the model of the "generation of universities", which suggests that a generation emerges, deploys, and then gives way to the next generation; while universities of the past and the new generations may coexist for some time. To indicate different generations of universities we will use the notions "University 1.0", "University 2.0", "University 3.0", "University 4.0"5. The features of generations of universities are analyzed on philosophical and methodological level in the system of categories "activity-related - social anthropological". The article presents proception (anticipatory vision of the future) of the University 4.0 corresponding with the formation of the "cognitive society". In the analysis of generational changes of the university we also use a model of "overcoming - positing - deployment": the university of the next generation each time appears (is created) as opposing to some phenomena and trends in society, in culture and in the university itself; further, it posits something else instead of the overcomable - it unfolds the innovative practices with the new activity-related, social and anthropological content right on its "body". At the next step the university scales the promising practices - implements technologization of their basic components and begins to distribute them.

\subsection{University 1.0}

In the late Middle Ages, the activity takes the form of personal excellence - in craft, military, diplomacy, doctoring, preaching, reasoning aloud or in the conduct of the dispute. Unlike the later "industrial" activity, it is not broken split into functions or successively implemented actions and is realized in a holistic manner. It is personalized and is supported by the craft organization, which sets the external frameworks and regulations (e.g., for product quality and price). Characteristic (leading) forms of the social are the craft corporations and urban communities as conglomerates of corporations ("city as community of communities" (Weber, 2001)). 
A human is understood as creation and likeness of God - a partner of creation. Religious commandments, tradition and life in communities rural, parish, craft - set a strict "canon" of a human.

Culture of an epoch is a culture of a symbol-image (iconic, ritual and ceremonial).

The university

represents institutionalization of mental labour in the form of a craft corporation characteristic of the era (Le Goff, 2003). The university opposes "profane", overcomes syncretic consciousness characteristic of a peasant or an urban philistine. The university overcomes the "dispersibility" of intellectuals, concentrates their activity on one platform - disputes, delivery of discursive texts (lectures), writing of scientific treatises. It provides transmission of culture of dispute and discourse to the next generation of intellectuals. At the same time, deep within the University 1.0 "rationality" begins to take shape, which at the next phase will result in a confrontation between the secular-rational consciousness and the religious-dogmatic one.

The University 1.0 has turned education into quite a massive practice by the standards of the late Middle Ages. For example, at the end of the $14^{\text {th }}$ century in the University of Paris the number of students reached 4000 people (Documents on history..., 1973). A "material body" of the University 1.0 corresponds to the activities that fill it. These are lecture halls where lectures and debates take place, a library - texts storage (retaining knowledge and discourses).

\subsection{University 2.0}

In the New Time, which became the beginning of the industrial age, there is a radically different machine form of the organization of activity compared to agriculture and handicrafts, which implies partitioning of the activity into actions and operations, distribution of these actions between employees and the assembly of "machines" out of co-operating people - manufactories, factories (Shchedrovitskii, 2011: 41-49). The activity of an individual is reduced to carrying out certain functions and corresponding operations.

To build factories and plants, to equip them with "machines made of iron", a special type of knowledge is needed - about how the material things interact with each other. Therefore, at the beginning of the industrial age the production of scientific and engineering knowledge is rapidly deployed, technology emerges as a special form of presentation and normalization of the activity. Today the task of science is to create new knowledge as a basis for new technologies.

There is a gap: a frontier of activity and thinking - it is the work of scientists and engineers, but the university continues to support the old forms of thinking and activity and turns into a conservative force ("scholastic ${ }^{6}$ university"). The institutionalization of new forms of intellectual activity becomes urgent, which leads to the formation of a new generation of universities (for example, a concept of the University von Humboldt was focused on it).

The University 2.0 overcomes the scholastic forms of intellectual activity. It posits, deploys and reproduces intellectual activity emancipated from religion and scholasticism - empirical research, design of scientific models; later (in the $19^{\text {th }}-20^{\text {th }}$ centuries) - design of technologies and machines, structures, etc required for their implementation. The University became one of the actors in the deployment of industrial revolutions.

Social reality of the industrial era is undergoing transformation - from "organic" social forms of the agrarian era to "machine" forms. This means tougher functionalization of social, occupational, regional and other groups, clearer organization of interactions and exchanges, and creation of special "machines" for these interactions (infrastructures). Machine forms gradually penetrate into the different 
spheres of society: Machine-organized army, schooling - class-and-lesson system, etc. To a large extent the University is organized as a "machine of learning": curriculum is organized as a "conveyor", an educational process - as standard lectures and seminars; interactions of the participants are regulated and normalized.

A key component of the industrial era is large-scale urbanization. The influx of rural people into the city "washes out" the urban communes; a new citizen is a lorn creature, but at the same time is freer and less prone to social control. The industrial revolution and the workers' struggle for their rights transform the life of citizens: there is a working day with fixed hours, the public services on a new technological basis (water supply, sewerage, electricity) leads to reduction in domestic labour; all this resulted in a mass phenomenon - leisure-time.

A person of the industrial era is a contradictory creature. On the one hand, his activity is reduced to the function within an industrial machine - it is impersonal, "alienated" labour. On the other hand, a person (some social groups) builds material mechanisms and assembles people-functions into social and industrial machines. On the third hand, it is an emancipated human - he organizes his actions on the basis of his own intelligence, no longer under the care of God and the church, not depending on the feudal lord; as a citizen, he is more liberated from the routine of everyday life.

By forming a scientific world view of human the University 2.0 forms it as free, independently and rationally thinking and acting. At the same time it creates the ability to act as a professional as part of the professional culture of thought and action.

Culture of the industrial era is the culture of action when action is cultivated, which is 1) justified, rationalized, 2) instrumentally equipped; it is a "technological" action. The technology, as opposed to individual mastery, is depersonalized, generalized and rational.

The "material body" of the University 2.0 is different from the material shell of the University 1.0 in the same way as the activities that fill them are different. In addition to classrooms and libraries, it includes laboratories required to obtain empirical knowledge, to conduct research and experiments.

\subsection{University 3.0}

The University 3.0 occurs at a time when the industry reaches its maturity and the "postindustrial transition" begins. A superstructure over the industry is being formed - companies that use plants and factories as a material by forming complex configurations of the activity, including development of models of new products (industrial laboratories), production chains (factories), sales of products and the development of markets (sales and marketing departments), after-sales service for product users (service units) (Post-industrial transition..., 2005). We can say that it is "meta-machines" built over the mashines which include human activities and engines. A system of activities of the superindustrial $^{7}$ era includes: design, construction of meta-machines; ensuring the functioning of the included machines (production, service); ensuring communications.

Due to the high performance of metamachines, a significant portion of people turns out to be excluded from the industry. In many research works, the post-industrial transition is conceived as the deployment of sectors of services, trade, finance, creative industries. Industry both folds and unfolds covering new footholds - there is industrialization of consumption, industrialization of services (those that are addressed to the mass consumer). Sales factories emerge - megamalls and supermarkets, factories of impressions - film production, TV shows, etc. 
It is important that the activity reproduction units are changing: a classic profession as a stable set of competencies goes to the past. The content and contexts of activity of a working man are repeatedly changing during his professional career, so the competence packages are becoming the activity reproduction units - configurations of knowledge and experience that allow a person to act, think and communicate in the event of new problems and contexts.

Social reality is changing. A range of social and economic actors is expanding - these are large companies, small firms, network organizations and non-profit organizations. "Regular relations" and related institutions are becoming less stringent (see. P. 3.5). A "social machine", in which it was possible to distinguish sharply defined functional places, is replaced by a different type of social reality. A system-forming value of interactions, communications and a derivative character of "groups" and "identities" are becoming more obvious in it. It can be described as a "social matrix", the content (activities) and institutional forms of which are very mobile and diverse.

In contrast to the industrialized world, a person is not a function in the machines of activities - it performs functions, but in a temporary and conditional way. A person realizes himself through the activity-related positions and social roles that he changes. Much of his life can unfold beyond the roles defined from the outside, as his personal "enterprise", realization of his individuality (this aspect of a human being was covered by J. Habermas through the concept of "performative existence" (Habermas, 1991: 195206)). A person finds intentionality in respect of his own identity, which can be broken down and rebuilt on new grounds.

Culture of the post-industrial phase is primarily a culture (cultivation) of communication and sociability. Construction of general contexts and creation of complex forms of the activity organization (meta-machines), interaction of active people outside unified "identities" - all this requires advanced, sophisticated culture of communication.

The University 3.0 is an institutional form for the implementation of a whole package of activities. The deployment of meta-machines requires a deep study of the corresponding rational grounds; however the scientific and engineering knowledge is no longer enough, new research subjects are unfolding-knowledge about economy and markets, about society and culture. In the University 3.0 the educational and scientific divisions of the economic and humanities fields move to the forefront. It also requires design of the activity and its components, therefore, policy and change management are becoming important subject; just and management and innovation management; social design and engineering; digital technical design; design and construction of signs and symbolic systems; foresight and studies of the future.

The University 3.0 overcomes "the study of the world as it is" deploying the project work and "the creation of new practices". It stands against the "industrial" universities with their inert educational process, which involves rapidly aging standard course packages; it problematizes their machine-like academic environment.

In addition to classrooms, libraries, laboratories, the "material body" of the University 3.0 also includes business incubators and technology parks, design offices, project offices, special platforms for communication with the outside world - exhibition spaces, community centres.

\subsection{University 4.0}

The University of the Fourth Generation can be described only in a sketch and project way since the appropriate reality ("cognitive world", “cognitive society”) is only being formed. 
The specifics of the activity of the cognitive era are related to the fact that new knowledge begins to play a key role in the creation of anything and the collective intelligence becomes a producer of knowledge. It is in the collective form (in the form of work of sophisticated "teams" that attract experts, users, etc. to their activities) that the meta-machines and the environment of their existence (natural, economic, social) are studied and designed; proception on the meta-machines, society, culture and human is realized (in this regard the emerging practice of foresight can be applied). Accordingly, collective thinking becomes the priority object of efforts to technologizing ${ }^{8}$. The digital revolution creates the technical basis for technologization of thinking by several directions: 1) technologization of thinking and communication of people; 2) creation of artificial intelligence and hybrid kinds of intelligence combining human and machine intelligence.

Virtual objects and virtual reality play a special role. In the cognitive world they are specially created as a "trial bodies" and "testing stands" that test new principles, forms, structures, technologies (of anything) ${ }^{9}$. On the other hand, they get a self-valuable, all-sufficient character they become high-grade forms of implementation of activities, the existence of society, personal fulfilment.

The society is characterized by: 1) spread of the network organization; 2) strengthening of the possibilities of individual actors (individuals and groups); 3) diversification by cultural grounds and alleged future - different actors act as carriers and implementers of different images of the future; society turns into the "world of worlds" - a space of self-determination, activity and interaction of groups with different cultures and future images.

A person is granted unprecedented opportunities for positing - mental, project and activity-related - of the "new reality". It is about access to technology, knowledge and information; to communication and education; about the amount of free time, availability of sites for trial actions. An individual person can conceive and carry out not only a separate project; the formation of a sufficiently large and growing area of new phenomena in almost any field can become the result of his creativity and efforts - an example would be the establishment of digital platforms for social networking on the Internet.

On the other hand, unprecedented opportunities are risks for a person to "disintegrate" in an infinite number of trial actions, self-education directions and virtual identities. "Arrangement" and "fixation" of a person becomes a special task - but not forcefully from the outside, but with his own effort on value grounds he accepted (O.G. Genisaretskii (1995) discusses a value self-image as a means for human to hold up).

A special culture needed for the cognitive era is the culture of the will, i.e., concentrations, focus of activity, retention of meanings and ideas, critical filtration of information and communications.

The University 4.0 overcomes "reproduction of the given" - given grounds and the forms of thinking and activity. It becomes a very open environment - a hub for a variety of communications, a node at the intersection of multiple networks - information, social, activity-related. These communications, research works and development projects involve not only professors and students, but also a wide range of external participants. We can say that the University of the Fourth Generation is an infrastructure platform for the deployment of a wide variety of search activities (research, project, development of new practices). For these activities the university offers itself as a platform to a variety of subjects (individual and institutional), 
provides opportunities for communication and navigation.

The community of intellectuals, on the one hand, and the material-institutional platform that provides their activities, on the other, will be divided. Instead of the structure "working faculty attached to the University as the employer organization", there is another one: groups that put and solve problems in different areas - training, education, research, developments, deployment of projects, innovative entrepreneurship, all of which are in different combinations and proportions. The university will offer these groups various services, a "platform" and a material infrastructure. It becomes an "intelligent park" (by analogy with industrial parks), a "hub". Instead of the common processes there are individual trajectories both for those receiving education and for the employees who are not necessarily professors, scientists, etc., and can generate and implement unique competence packages.

Own key technologies of the University 4.0 are the cognitive technologies: 1) strengthening of human intelligence by computer technologies, creation of hybrid intellects, 2) technologies of formation and support of collective intelligence. The university, on the one hand, needs these technologies to fully implement its own "ideal form"; on the other hand, it can become the epicentre of formation and distribution of cognitive technologies.

In connection with the division of labour in the intellectual sphere, the accents will shift in the activities of the university: its function is primarily the formulation of goals and objectives for the research, the development of basic paradigms and concepts, and the research and development themselves will be carried out, on the one hand, by small companies and organizations, and on the other hand, by large and specialized, highly mechanized factories of the production of knowledge.

The complex reality of the University 4.0 includes: 1) formation of the bases of thought (categories, concepts, basic models), 2) production of fundamental knowledge; 3) development of technologies as a "implementation of knowledge into reality", 4) launch of start-ups, 5), deployment of communication networks; coordination of different subjects, 6) unfolding of new practices.

In addition to classrooms, libraries, laboratories, business incubators, technology parks and community centres, the "material body" of the University 4.0 also includes infrastructure of communications and telecommunications.

\footnotetext{
The latter, of course, is occurring not in an explicit way, in the course of lecture-discussion process, but in the university space. An example from history can be the establishment of an empiricist-scientist as a new anthropo-type.

2 Throughout the $20^{\text {th }}$-beginning of the $21^{\text {st }}$ centuries, the dynamics of the share of industry in total world production has a wavelike nature, which is associated with overlaying of two processes - the post-industrial transition in developed countries and the industrialization of developing countries (Rodionova, 2010: 40).

For example, such forms of cooperation as a "virtual enterprise" are currently being tested.

4 That is technologies ensuring the formation of collective intelligence (its set of the individual - human and artificial - intelligences) and its effective functioning.

5 Currently, such a designation of generations is widely used to refer to a variety of subjects.

6 Scholasticism here means not only medieval religious philosophy, but also, more broadly, the culture of thought, which is characterized by adherence to a letter and spirit of authoritative texts, restrictions on reflection and criticism of the content of these texts, belittling of the role of experience.

7 Some researchers insist that the term "super-industrial" era is more accurate than the "post-industrial", since the industry does not disappear, does not remain in the past, but is included in the more complex systems. For example, the term was used by E. Toffler.

8 About technologization of thinking, see, for example, Shchedrovitskii, 2011.

9 Compared to J.K. Jones's (1986) thoughts about the opportunities that have arisen as a result of the drawing design: "when the geometric aspects of production are shown in the drawing, a designer can see the product as a whole, can control it... with a ruler and a compass he can easily find a trajectory of every detail and determine how changing the shape of one of the details will affect the design of the entire product... a drawing is an easily modified model of relations between details...
} 
this model is easy to understand and change, and is able to store a temporary solution for one detail, while another is being worked out, thus the designer is able to solve problems of such an unimaginable complexity that their solution in other ways would be impossible".

Virtual objects, as opposed to drawing, help to simulate, study, modify systems that are infinitely more difficult than those made of details, and for the understanding of which it is sufficient to retain geometric configuration. Virtual objects and realities turn the non-physical systems and realities - ecosystems, sociosystems, polysystems etc. into an object of experimentation and construction.

\section{References}

A post-industrial shift in Russian higher education: by an example of the analysis of the market of educational services of the North-West Russian Federation. The report of the Foundation of the "Center for Strategic Research "North-West” (2005). St. Petersburg, 127 p.

Abankina, I.V., Abankina, T.V., Filatova, L.M., Nikolaenko, E.A. (2012). Tendentsii izmeneniia obshchestvennogo sprosa na vysshee obrazovanie $\mathrm{v}$ sovremennoi Rossii [Trends in the social demand for higher education in today's Russia], In Voprosy obrazovaniia [Education issues], $3,88-112$.

Abankina, I.V., Abankina, T.V. (2013). Mesto vuzov v novoi ekonomike: strategii i ugrozy [Place of universities in the new economy: strategies and threats], In Otechestvennye zapiski [Local Notes], 4, 171-180.

Barnett, R. (2001). Osmyslenie universiteta [Comprehension of the University]. Education in Modern Culture, Minsk, 97-124.

Bell, D. (1999). Griadushchee postindustrial'noe onshchestvo: Opyt sotsial'nogo prognozirovaniia [The upcoming post-industrial society: Experience of social forecasting]. Moscow, Academia, $956 \mathrm{p}$.

Castells, M. (1999). Stanovlenie obshchestva setevykh struktur [Formation of the network structures society]. Novaia postindustrial'naia volna na Zapade. Antologiia [The new post-industrial wave in the West. Anthology], 494-505.

Castells, M. (2000). Informatsionnaia epokha: ekonomika, obshchestvo i kul'tura [The Information Age: Economy, Society and Culture]. Moscow, GU VSHE, 608.

Didenko, D.V., Latov, Iu.V. (2013). Evoliutsiia obrazovatel'nykh sistem kak instituta industrial'nogo i postindustrial'nogo razvitiia [The evolution of the educational system as an institution of industrial and postindustrial development], In Istoriko-ekonomicheskie issledovaniia [Historical and economic studies], 14 (3), 101-128.

Documents on the history of European universities in the $12^{\text {th }}-15^{\text {th }}$ centuries. (1973). Voronezh, VSPI, $157 \mathrm{p}$.

Efimov, V.S., Lapteva, A.V. (2011). Budushchee vysshego obrazovaniia v Rossii: ekspertnoe videnie [The future of higher education in Russia: expert vision], In Universitetskoe upravlenie: praktika i analiz [University Management: Practice and Analysis], 4 (74), 52-64.

Efimov, V.S., Lapteva, A.V. (2014). Kognitivnyi universitet: kontury budushchego [Cognitive University: the contours of the future], In Universitetskoe upravlenie: praktika i analiz [University Management: Practice and Analysis], 6 (94), 18-29.

Efimov, V.S., Lapteva, A.V., Dadasheva, V.A. (2012a). Forsait vysshei shkoly Rossii: novye missii i funktsii, perspektivnye tekhnologii i formaty deiatel'nosti [A foresight of a higher school of Russia: new missions and functions, advanced technologies and formats of activities], In Universitetskoe upravlenie: praktika i analiz [University Management: Practice and Analysis], 3 (79), 13-48. 
Efimov, V.S., Lapteva, A.V., Rumiantsev, M.V., Dadasheva, V.A., Efimov, A.V. (2012b). Budushchee vysshei shkoly Rossii: ekspertnyi vzgliad. Forsait issledovanie - 2030: analiticheskii doklad [The future of a higher school in Russia: expert opinion. Foresight Study - 2030: analytical report]. Krasnoyarsk Siberian Federal University, 181 p.

Galushkina, M., Kniaginin, V. (2005). Massovoe, gibkoe i internatsional'noe [The mass, the flexible and the international], In Ekspert [Expert], 43 (489).

Genisaretskii, O.I. (1995). Kul'turno-antropologicheskaia perspektiva [The culturalanthropological perspective]. Readings of the new Russian self-consciousness, available at: http://old. russ.ru/antolog/inoe/index.html

Gimpelson, V., Kapeliushnikov, R., Karabchuk, T., Ryzhikova, Z., Biliak, T. (2009). Vybor professii: chemu uchilis' i gde prigodilis'? [The choice of profession: what did we learn and where did we come in useful?]. Moscow, GU VSHE, 64.

Habermas, J. 1991. Poniatie individual'nosti, O chelovecheskom v cheloveke [A concept of individuality, on the human in a person]. Moscow, Politizdat, $384 \mathrm{p}$.

Inglehart, R. (1997). Modernization and Postmodernization. Cultural, Economic and Political Change in 43 Societies. Princeton, Princeton Univ. Press,

Inozemtsev, V.L. (1995). K teorii postekonomicheskoi obshchestvennoi formatsii [On the theory of post-economic formation of society]. Moscow, Taurus, Century, $330 \mathrm{c}$.

Jaspers, K. (2006). Ideia universiteta [An idea of the university]. Minsk, BSU, 159 p.

Jones, J.K. (1986). Metody proektirovaniia [Design methods]. Moscow, Mir, 326 p.

Kliachko, T.L., Mau, V.A. (2015). Budushchee universitetov [The future of universities]. Moscow, "Delo", RANKhiGS, 64 p.

Kniazev, E.A., Drantusova, N.V. (2012). Differentsiatsiia v vysshem obrazovanii: osnovnye kontseptsii i podkhody $\mathrm{k}$ izucheniiu [Differentiation in higher education: basic concepts and approaches to the study], In Universitetskoe upravlenie: praktika i analiz [University Management: Practice and Analysis], 5 (81), 43-52.

Kniazev, E.A., Drantusova, N.V. (2013). Institutsionnaia dinamika v rossiiskom vysshem obrazovanii: mekhanizmy i traektorii [Institutional dynamics in Russian Higher Education: mechanisms and trajectories], In Universitetskoe upravlenie: praktika i analiz [University Management: Practice and Analysis], 1 (83), 6-17.

Kuz'minov, Ia.I. (2007). Nashi unversitety [Our universities], In Universitetskoe upravlenie: praktika i analiz [University Management: Practice and Analysis], 3, 11-14.

Kuz'minov, Ia.I., Frumin, I.D. (2015). Onlain-obuchenie: kak ono meniaet strukturu obrazovaniia i ekonomiku universiteta [Online learning: how it changes the structure of education and economy of the University]. Open discussion of Ia.I. Kuz'minov - M. Karnoi, In Voprosy obrazovaniia [Education issues], 3, 8-43.

Le Goff, J. (2003). Intellektualy v Srednie veka [Intellectuals in the Middle Ages]. St. Petersburg, Publishing House of St. Petersburg University Press, 160 p.

Liubimov, L.L. (2009). Ugasanie obrazovatel'nogo etosa [Fading of the educational ethos], In Voprosy obrazovaniia [Education issues], 1, 199-210.

Machlup, F. (1966). Proizvodstvo i rasprostranenie znanii v SSHA [Production and distribution of knowledge in the United States]. Moscow, Progress, $462 \mathrm{p}$. 
Mau, V.A. (2013). Chelovecheskii kapital: vyzovy dlia Rossii [Human Capital: Challenges for Russia]. Moscow, Publishing House "Delo", RANKhiGS, 32 p.

Ogurtsov, A.P., Platonov, V.V. (2004). Obrazy obrazovaniia. Zapadnaia filosofiia obrazovaniia. 20 vek [Images of Education. Western philosophy of education. The twentieth century]. Moscow, Publishing House of the Russian Christian Humanitarian Institute, $520 \mathrm{p}$.

Pereslegin, S.B. (2007). Samouchitel' igry na mirovoi shakhmatnoi doske [Self-teaching guide for the world chessboard]. Moscow, AST; St. Petersburg, Terra Fantastica, 619 p.

Pokrovskii, N.E. (2005). Pobochnyi product globalizatsii: universitety pered litsom global'nykh izmenenii [A by-product of globalization: universities in the face of global changes], In Obshchestvennye nauki i sovremennost' [Social sciences and modernity], 4, 148-154.

Rodionova, I.A. (2010). Mirovaia ekonomika: industrial'nyi sektor [The World Economy: Industrial sector]. Moscow People's Friendship University, 606 p.

Readings, B. (1996). The university in ruins. Cambridge: Harvard University Press.

Rozin, V.M. (2007). Refleksiia obrazov i sfery obrazovaniia [Reflection of images and education]. Available at: http://www.fondgp.ru/lib/mmk/46/\#_ftnref16 (accessed 15 September 2016).

Shchedrovitskii, P.G. (2011). Povestka dnia 2010-kh [The agenda of the 2010's]. Lecture series. Available at: http://www.fondgp.ru/lib/mmk/180 (accessed September 8, 2016).

Stouner, T. (1986). Informatsionnoe bogatstvo: profil' postindustrial'noi ekonomiki [Information wealth: a profile of the post-industrial economy], In Novaia tekhnokraticheskaia volna na Zapade [A new technocratic wave in the West]. Moscow, Progress, 392-409.

Towards Knowledge Societies. (2005). UNESCO, 239 p.

Weber, M. (2001). Istoriia khoziaistva. Gorod [History of economy. City]. Moscow, Kanon-pressTs, Kuchkovo pole, 576 p.

\section{Новое поколение университетов.}

\section{Университет 4.0}

А.В. Лаптева, В.С. Ефимов

Сибирский федеральный университет Россия, 660041, Красноярск, пр. Свободный, 79

\footnotetext{
Происходящие в настоящее время изменения университетов рассматриваются в логике смены фаз соииально-экономического развития - как аспект постиндустриального перехода. Содержание фаз развития общества и университета осмысливается посредством категорий «деятельностное - социальное - антропологическое». Выделены четыре «поколения» университетов, соответствующие доиндустриальной, индустриальной, постиндустриальной и когнитивной фазам. Для анализа переходов от одного поколения к другому используется схема «преодоление - полагание - развертывание» (форм деятельности, институциональных форм, форм сознания и мышления, картин мира). Обсуждаются особенности университета в будущем- университета 4.0.
}

Ключевые слова: университеты, постиндустриальный переход, фазовые трансформации, университет в соииуме, поколения университетов, университет 4.0. 
Исследование выполнено при финансовой поддержке РГНФ и КГАУ «Красноярский краевой фонд поддержки научной и научно-технической деятельности» в рамках научноисследовательского проекта «Университеты в ситуачии постиндустриального перехода: новые функции и модели развития» (проект № 16-16-24011).

Научная специальность: 08.00.00 - экономические науки. 